\title{
ANALISIS DAMPAK PEMBUKAAN GALIAN UNTUK CONNECTING BASEMENT TERHADAP BANGUNAN EKSISTING DENGAN METODE FINITE ELEMENT
}

\author{
Della Amelia ${ }^{1}$, Inda Sumarli², Ali Iskandar ${ }^{3}$ \\ ${ }^{1}$ Program Studi Sarjana Teknik Sipil, Universitas Tarumanagara \\ Email:dellaamelia.da@gmail.com \\ ${ }^{2}$ Program Studi Sarjana Teknik Sipil, Universitas Tarumanagara \\ Email: indas@ft.untar.ac.id \\ ${ }^{3}$ Program Studi Sarjana Teknik Sipil, Universitas Tarumanagara \\ Email: Ali.iskandar1999@gmail.com
}

Masuk: 24-01-2021, revisi: 03-10-2021, diterima untuk diterbitkan: 09-10-2021

\begin{abstract}
ABSTRAK
Pada suatu konstruksi galian dalam yang berdekatan dengan suatu bangunan lain dikhawatirkan akan memberikan dampak atau efek yang buruk terhadap bangunan di sekitarnya. Efek dari galian dalam tersebut menyebabkan terjadinya deformasi pada struktur dari bangunan di sekitarnya akibat dari pergerakan tanah dan penurunan permukaan tanah di belakang dinding yang dapat menyebabkan bangunan tersebut menjadi miring. Tujuan dari penelitian ini yaitu untuk mengamati pengaruh pekerjaan galian dalam (basement dengan 7 lantai) yang berdekatan dengan bangunan sekitar dengan basement 5 lantai dan 7 lantai yang berlokasi di Jakarta Selatan. Basement yang dimodelkan terkoneksi dengan basement dari bangunan eksisting sehingga diamati pengaruh bukaan dinding diafragma untuk connecting basement terhadap struktur bawah bangunan eksisting. Penelitian ini dilakukan dengan melihat deformasi yang terjadi pada dinding diafragma dari bangunan eksisting, dan juga mengamati gaya-gaya dalam yang bekerja pada pelat lantai basement dari bangunan eksisting. Pengamatan dilakukan dengan menggunakan program elemen hingga tiga dimensi dengan model material yang paling umum digunakan yaitu Hardening Soil untuk analisis galian dalam. Analisis dilakukan dengan kondisi drained dengan tipe kalkulasi phreatic serta hanya memperhitungkan keadaan static. Hasil menunjukkan bahwa defleksi yang terjadi setelah tahapan terakhir pekerjaan galian dalam yaitu masih dalam batas yang diijinkan menurut SNI 8460:2017 yaitu dibawah dari $14 \mathrm{~cm}$ pada dinding diafragma bangunan eksisting.
\end{abstract}

Kata Kunci: Galian Dalam; Dinding Diafragma; Connecting Basement; Hardening Soil; Elemen Hingga

\section{ABSTRACT}

In a deep excavation construction that adjacent to the existing buildings there is a concern that it will have a bad impact or effect on adjacent buildings. The effect of deep excavation induced deformation of the existing structures due to ground movements and ground surface settlement behind the wall which can cause a tilt of the building. The objective of this study is to observe the effect of deep excavation ( 7 storey basement) adjacent to the existing buildings with 7 and 5 storey basement located in South Jakarta. The basement is connected to the basement of the existing building so that the effect of diaphragm wall opening for connecting basement towards the substructures of the existing building is observed. This study was conducted by observing the deformation that occurs in the diaphragm of the existing building, and also observing the internal forces acting on the basement floors slabs of the existing buildings. Observations were made using a three-dimensional finite element program with the most commonly used material model for analysis of deep excavation, The Hardening Soil Model. The analysis was performed with drained conditions with phreatic calculation type and only calculated the static conditions. Results indicate that the deflection that occurs after the final stage of excavation is still within the allowable limit according to the SNI 8460:2017, which is less than 14 centimeters on the diaphragm wall of the existing buildings.

Keywords: Deep Excavation; Connecting Basement; Diaphragm Wall; Hardening Soil; Finite Element 


\section{PENDAHULUAN}

\section{Latar belakang}

Sistem penahan tanah untuk galian dalam terdiri dari berbagai macam jenis, seperti sheet pile walls, braced walls, pile walls, dan diaphragm walls. Galian dalam didesain agar stabil dan meminimalkan deformasi akibat penggalian yang dimana nilai tersebut masih dapat diterima pada bangunan yang berdekatan. Efek dari galian dalam tersebut menyebabkan terjadinya deformasi pada struktur dari bangunan di sekitarnya akibat dari pergerakan tanah yang menyebabkan bangunan tersebut menjadi miring. Respon dari bangunan tersebut akibat pergerakan dari tanah yaitu dapat terjadi crack dan deformasi pada strukturnya (Dinakar \& Prasad, 2013). Ilustrasi efek dari galian dalam tersebut terhadap bangunan di sekitarnya seperti pada Gambar 1.

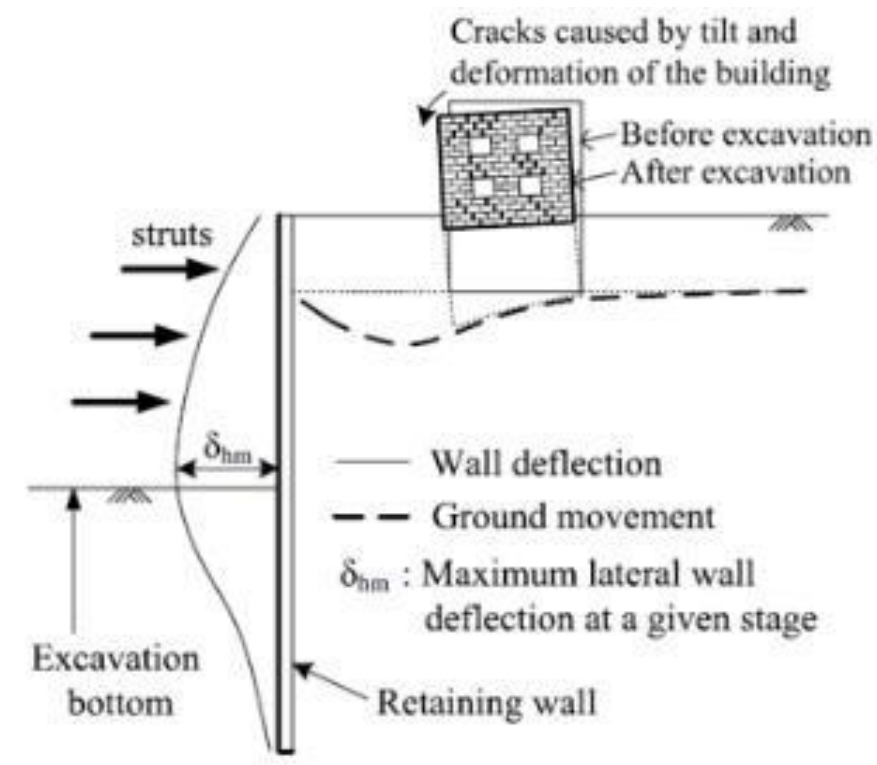

Gambar 1. Respon dari struktur terhadap galian dalam Sumber: Kung dkk., 2007

Pergerakan tanah dari penggalian menyebabkan ketidakstabilan gaya yang bekerja pada dinding dikarenakan penggalian dari tanah di area ekskavasi. Besarnya gaya yang tidak stabil tersebut dipengaruhi oleh banyak hal seperti kondisi dari lapisan tanah, tekanan air tanah, kedalaman penggalian, lebar dari penggalian dan sebagainya. Metode elemen hingga dapat menyimulasikan faktor-faktor tersebut dan hasil dari analisis tersebut cukup akurat dibandingkan dengan rumus stabilitas yang sederhana dan metode empiris lainnya. Oleh karena itu, metode elemen hingga telah dipakai pada beberapa analisis permasalahan galian dalam (Ou, 2016). Metode elemen hingga merupakan metode yang secara teori lengkap namun masih relatif sederhana dalam memodelkan perilaku tanah. Akan tidak mungkin untuk dua user dengan software yang sama serta memodelkan masalah yang sama memiliki hasil/results yang sama (Gaba dkk., 2002).

Metode konstruksi top-down merupakan metode konstruksi struktur bawah tanah yang dilakukan dari permukaan tanah sampai ke dasar galian sambil dengan membangun struktur atasnya. Pada metode ini, konstruksi dari pelat lantai dilakukan setelah melakukan penggalian dari tiap lantai tersebut. Seiring dengan berlangsungnya konstruksi dari pelat dan penggalian, dilakukan juga konstruksi untuk struktur atas. Oleh sebab itu, metode ini cenderung lebih cepat tahapan konstruksinya dibandingkan metode konvensional pada umumnya, namun metode ini membutuhkan biaya yang sangat tinggi (Ou, 2006). Sedangkan metode konstruksi semi top-down mirip dengan metode konstruksi top-down hanya perbedaannya adalah pada semi top-down 
konstruksi struktur bawah diselesaikan terlebih dahulu lalu kemudian dilanjutkan dengan struktur atasnya.

Berbeda dengan penelitian yang dilakukan oleh Dinakar dan Prasad, pada penelitian ini basement dari kedua bangunan yang berdekatan tersebut terkoneksi/terhubung. Basement tersebut terhubung dengan adanya bukaan pada dinding pada elevasi -10 m hingga lantai dasar basement (Gambar 2). Bangunan $\mathrm{A}$ dan bangunan $\mathrm{C}$ merupakan bangunan eksisting yang akan ditinjau pada penelitian ini. Penelitian dilakukan dengan melihat efek atau pengaruh dari pekerjaan galian bangunan B dan connecting basement terhadap deformasi dari struktur bawah bangunan eksisting tersebut. Site plan lebih jelasnya dapat dilihat pada Gambar 2. Metode konstruksi yang digunakan pada galian dalam ini yaitu metode semi top-down. Analisis digunakan dengan bantuan program finite element 3D. Elevasi basement dapat dilihat pada Gambar 3.

\section{Rumusan masalah}

Mengetahui bagaimana efek atau pengaruh dari pekerjaan galian dalam yang berdekatan dengan bangunan di sekitarnya dan bukaan/opening dinding diafragma terhadap bangunan eksisting tersebut

\section{Tujuan penelitian}

Berdasarkan rumusan masalah tersebut, tujuan penelitian ini yaitu menganalisis defleksi lateral pada dinding diafragma pada masing-masing bangunan eksisting untuk mengetahui pengaruh dari pekerjaan galian dalam tersebut terhadap bangunan eksisting, menganalisis gaya aksial pada pelat lantai basement bangunan $\mathrm{C}$ untuk mengetahui pengaruh dari bukaan pada dinding diafragma untuk connecting basement, serta melakukan pengecekan stabilitas dari dasar galian dalam tersebut.

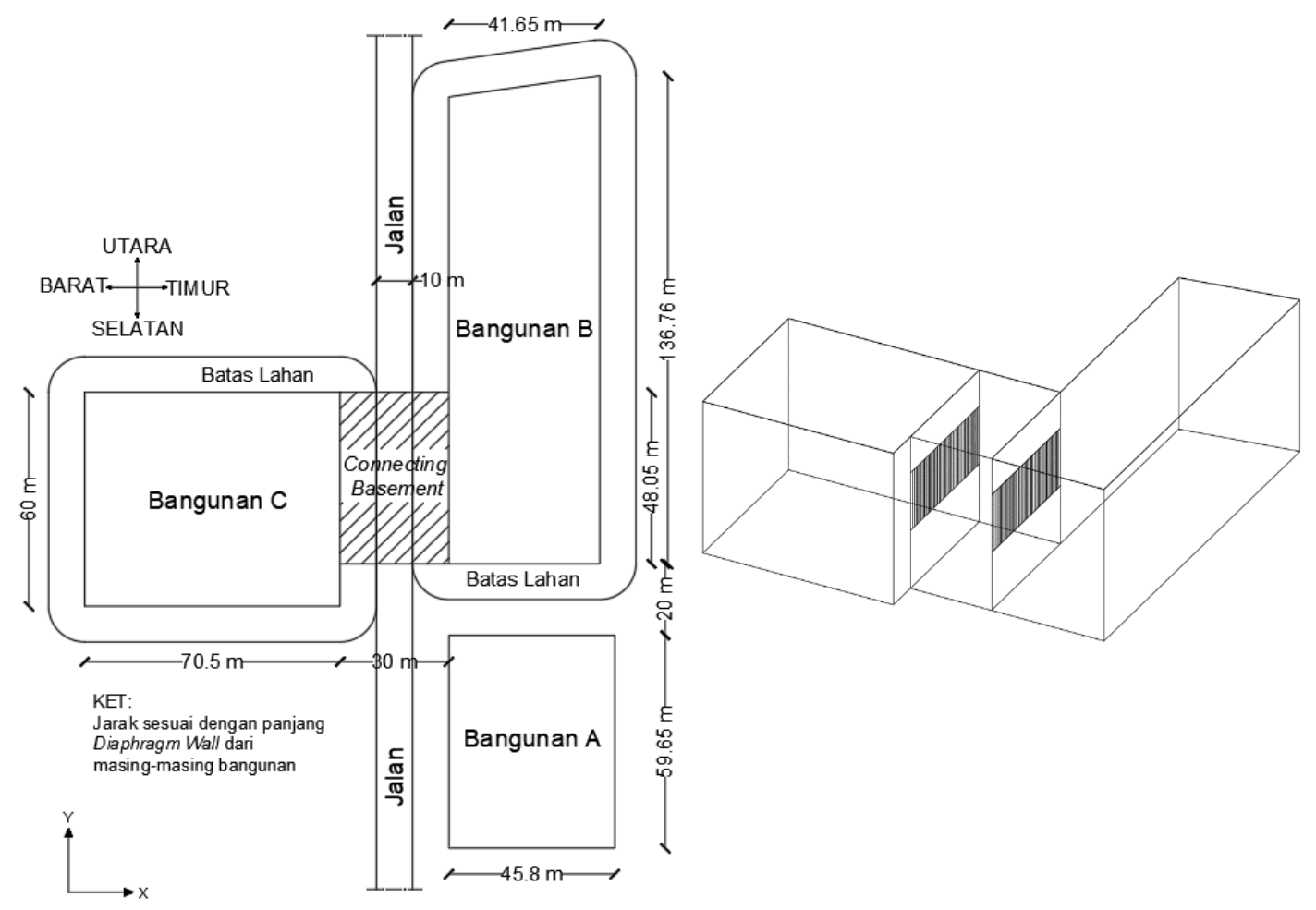

Gambar 2. Site plan lokasi basement masing-masing bangunan (kiri) dan posisi opening/bukaan pada dinding diafragma bagian yang diarsir (kanan) 

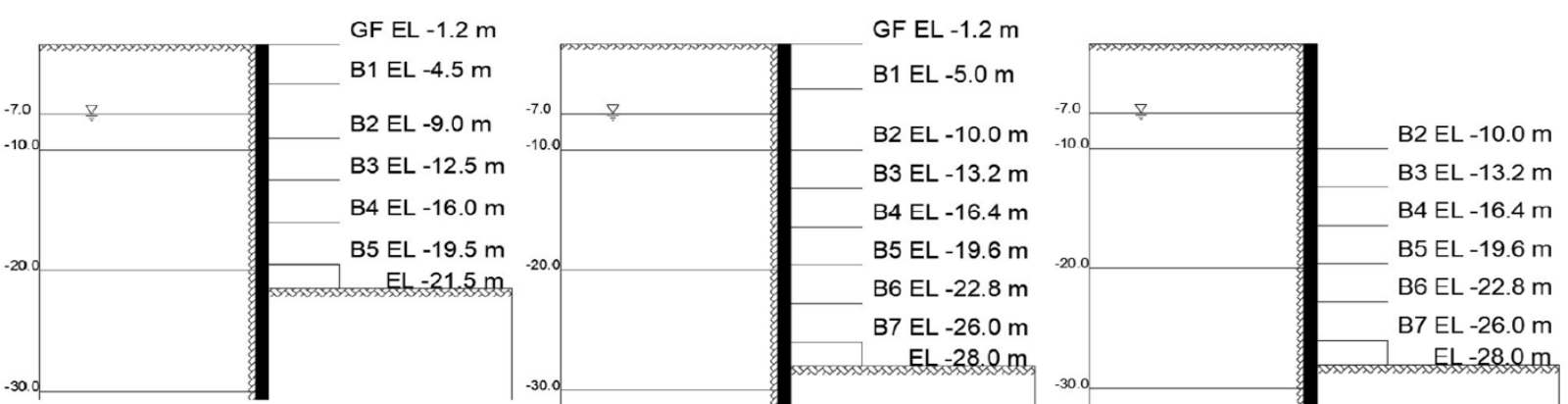

Gambar 3. Potongan elevasi basement masing-masing bangunan

Lantai basement terpilih pada basement bangunan B, C dan connecting basement yaitu pada B2, B4, dan B6 karena lantai B3 dan B5 yang sementara tidak dilakukan pengecoran (dihilangkan). Untuk bangunan B, C dan connecting basement, tahapan semi top-down dimulai dari B1, B2, B4, B6, B7 (raft foundation), pemasangan kolom lalu pemasangan pelat lantai B3, B5, dan GF. Untuk bangunan A tahapan dimulai dari GF sampai dasar basement tanpa penghilangan ring slab kemudian dilanjutkan dengan pemasangan kolom dan pemberian beban struktur atas. Masingmasing bangunan diberikan beban tepi galian sebesar $10 \mathrm{kPa}$ selama tahapan konstruksi dilakukan.

\section{METODE PENELITIAN}

\section{Pengumpulan data}

Pada penelitian ini, data tanah berasal dari salah satu proyek yang berlokasi di Jakarta Selatan. Data tanah yang dikumpulkan antara lain data boring log, data Pressure Meter Test (PMT), serta data dari hasil uji laboratorium. Data untuk Bangunan A terdiri dari 3 boring log serta data laboratorium. Data untuk bangunan B dan C terdiri dari 13 boring log, serta 21 tes untuk PMT. Rekapitulasi data tanah dapat dilihat pada Tabel 2.

\section{Tahapan penelitian}

Tahapan dimulai dari studi literatur mengenai galian dalam dan dilanjutkan dengan pengumpulan data dan pengolahan data. Pengolahan data yang dilakukan seperti menginterpretasikan parameter tanah yang akan digunakan serta menentukan parameter tanah dan struktural dalam analisis dengan elemen hingga. Pemodelan hanya sampai ketika pekerjaan basement (Bangunan B dan connecting basement) telah selesai sehingga beban bangunan dari bangunan B tidak dimodelkan. Analisis dilakukan dengan menggunakan program elemen hingga tiga dimensi dengan model material Hardening Soil. Analisis dilakukan dengan kondisi drained dengan tipe kalkulasi phreatic serta hanya memperhitungkan keadaan static. Setelah seluruh data telah lengkap kemudian dilanjutkan dengan memodelkan kondisi bangunan dan galian serta beban-beban yang bekerja dengan asumsi beban bangunan sebesar $10 \mathrm{kN} / \mathrm{m}^{2}$ yang dimodelkan sebagai point load. Hasil dari program kemudian dianalisis untuk nilai defleksi pada dinding diafragma dan gaya aksial pada pelat lantai. Untuk mengecek stabilitas global dan lokal (basal heave) dilakukan pengecekan angka keamanan dengan merujuk pada SNI 8460:2017.

\section{HASIL DAN PEMBAHASAN}

\section{Deskripsi umum bangunan}

Pada penelitian ini, bangunan yang akan dianalisis berlokasi di Jakarta Selatan. Ketiga bangunan ini merupakan bangunan multifungsi yang digunakan sebagai pusat perbelanjaan, hotel, 
perkantoran, dan hunian apartemen. Bangunan A dan B berjarak $20 \mathrm{~m}$ dan Bangunan B dan C berjarak $30 \mathrm{~m}$ dengan diantaranya terdapat connecting basement (Tunnel). Data dari masingmasing struktur dapat dilihat pada Tabel 1.

Tabel 1. Rekapitulasi spesifikasi struktur

\begin{tabular}{|c|c|c|c|c|c|}
\hline & & Bangunan A & Bangunan C & Bangunan B & Tunnel \\
\hline Jumlah & antai Basement & 5 Lantai & 7 Lantai & 7 Lantai & 5 Lantai \\
\hline \multirow{5}{*}{$\begin{array}{l}\text { Diaphragm } \\
\text { Wall }\end{array}$} & Panjang (m) & 59,65 & 70,5 & 136,76 & 48,05 \\
\hline & Lebar (m) & 45,8 & 60 & 41,65 & 30 \\
\hline & Top Level (m) & $-1,2$ & $-1,2$ & $-1,2$ & $-1,2$ \\
\hline & Toe Level (m) & -32 & -55 & -55 & -55 \\
\hline & Tebal $D$-Wall $(\mathrm{m})$ & 0,8 & 1 & 1 & 1 \\
\hline \multirow[b]{3}{*}{ Bored Pile } & C.O.L (m) & $-21,5$ & -28 & -28 & -28 \\
\hline & Toe Level (m) & -50 & -65 & -65 & -65 \\
\hline & $\begin{array}{c}\text { Diameter } \\
\text { bored pile }(\mathrm{m})\end{array}$ & $\begin{array}{c}0,8 \\
1 \\
1,2\end{array}$ & 1,5 dan 1,8 & 1,2 & 1,5 \\
\hline King Post & Material & $\begin{array}{l}\text { KC } 588 \times 300 \times 12 \times 20 \\
\text { KC } 700 \times 300 \times 13 \times 24\end{array}$ & HC478x417x30x60 & \multicolumn{2}{|c|}{ KC700x300x13×24 } \\
\hline Ring Slab & Tebal (m) & 0,25 & 0,3 & 0,3 & 0,3 \\
\hline Kolom & $\begin{array}{c}\text { Ukuran (m) } \\
\{\text { Height } \times \text { width }\}\end{array}$ & $\begin{array}{l}1,2 \times 1,2 \\
0,8 \times 0,8\end{array}$ & $1,2 \times 1,2$ & $1,2 \times 1,2$ & $1,2 \times 1,2$ \\
\hline
\end{tabular}

\section{Tahapan analisis elemen hingga}

Pada analisis yang dilakukan, analisis dimodelkan dengan metode konstruksi semi top-down yang berarti konstruksi struktur bawah diselesaikan terlebih dahulu lalu kemudian dilanjutkan dengan struktur atas. Oleh karena itu, pada analisis yang dilakukan tidak memodelkan beban dari struktur atas bangunan B dan juga tunnelling (connecting basement) karena analisis hanya ditinjau saat setelah struktur basement bangunan B dan tunnel telah selesai lalu dinding diafragma dibuka. Pada program, bangunan A dimodelkan terlebih dahulu kemudian bangunan $\mathrm{C}$. Tahapan konstruksi bangunan $\mathrm{B}$ dan connecting basement dilakukan secara bersamaan setelah tahapan konstruksi bangunan $\mathrm{A}$ dan $\mathrm{C}$ selesai. Hasil pemodelan pada program finite element dapat dilihat pada Gambar 4.

Tabel 2. Rekapitulasi parameter tanah

\begin{tabular}{|c|c|c|c|c|c|c|c|c|c|c|}
\hline \multicolumn{3}{|c|}{ Kedalaman (m) } & \multirow{2}{*}{$\begin{array}{c}\mathrm{N}-\mathrm{SPT} \\
5\end{array}$} & \multirow{2}{*}{$\begin{array}{c}\text { Jenis Tanah } \\
\text { Silty Clay }\end{array}$} & \multirow{2}{*}{$\begin{array}{c}\text { Konsistensi } \\
\text { Medium }\end{array}$} & \multirow{2}{*}{$\begin{array}{c}\begin{array}{c}\gamma_{\text {unsat }} \\
\left(\mathrm{kN} / \mathrm{m}^{3}\right)\end{array} \\
16\end{array}$} & \multirow{2}{*}{$\begin{array}{c}\begin{array}{c}\gamma_{\text {sat }} \\
\left(\mathrm{kN} / \mathrm{m}^{3}\right)\end{array} \\
16,5\end{array}$} & \multirow{2}{*}{$\begin{array}{c}\begin{array}{c}\mathrm{Su} \\
(\mathrm{KPa})\end{array} \\
40\end{array}$} & \multirow{2}{*}{$\frac{\mathrm{Cc}}{0,55}$} & \multirow{2}{*}{$\begin{array}{c}\begin{array}{c}E^{\prime} \\
(\mathrm{KPa})\end{array} \\
9000\end{array}$} \\
\hline 0 & - & 10 & & & & & & & & \\
\hline 10 & - & 20 & 30 & Silty Clay & Very Stiff & 16 & 17 & 200 & 0,4 & 30000 \\
\hline 20 & - & 30 & 20 & Silty Clay & Very Stiff & 17 & 17,5 & 150 & 0,4 & 30000 \\
\hline 30 & - & 40 & 26 & Silty Clay & Very Stiff & 17 & 17,5 & 150 & 0,4 & 40000 \\
\hline 40 & - & 50 & 26 & Silty Clay & Very Stiff & 17 & 18,5 & 200 & 0,4 & 40000 \\
\hline 50 & - & 60 & 26 & Silty Clay & Very Stiff & 18 & 18,5 & 200 & 0,6 & 60000 \\
\hline 60 & - & 70 & 26 & Silty Clay & Very Stiff & 18 & 18,5 & 170 & 0,6 & 60000 \\
\hline 70 & - & 80 & 26 & Silty Clay & Very Stiff & 18 & 18,5 & 170 & 0,6 & 60000 \\
\hline 80 & - & 90 & 34 & Silty Clay & Hard & 18 & 18,5 & 170 & 0,6 & 60000 \\
\hline 90 & - & 100 & 34 & Silty Clay & Hard & 18 & 18,5 & 170 & 0,6 & 60000 \\
\hline 100 & - & 110 & 34 & Silty Clay & Hard & 18 & 18,5 & 170 & 0,8 & 60000 \\
\hline 110 & - & 120 & 34 & Silty Clay & Hard & 18 & 18,5 & 170 & 0,8 & 60000 \\
\hline
\end{tabular}


Kedalaman tanah untuk analisis elemen hingga dimulai dari elevasi -1,2 m yang mengikuti elevasi jalan pada daerah tersebut. Untuk pemodelan tanah dengan material Hardening Soil, parameterparameter pada reference pressure didapatkan berdasarkan korelasi dari nilai swelling index (Cs) menurut Lim dkk, (2010) dan korelasi parameter kekakuan lainnya menurut Calvello dan Finno (2004) dengan $E_{50}^{r e f}=\frac{1}{3} E_{u r}^{r e f}$ dan $E_{\text {oed }}^{r e f}=0,7 E_{50}^{r e f}$ serta angka faktor reduksi digunakan 0,7 untuk analisis interaksi struktur (beton) dan tanah menurut Brinkgreeve dan Shen (2011). Parameter untuk analisis elemen hingga dapat dilihat pada Tabel 3 di bawah ini.

Tabel 3. Input parameter hardening soil

\begin{tabular}{|c|c|c|c|c|c|c|c|c|c|c|c|c|c|}
\hline \multicolumn{3}{|c|}{ Kedalaman (m) } & \multirow{2}{*}{$\frac{\text { Cs }}{0,08}$} & \multirow{2}{*}{$\begin{array}{l}e_{0} \\
1,6\end{array}$} & \multirow{2}{*}{$\begin{array}{c}\begin{array}{c}E_{u r}^{r e f} \\
\left(\mathrm{kN} / \mathrm{m}^{2}\right)\end{array} \\
13472,55\end{array}$} & \multirow{2}{*}{$\begin{array}{c}\begin{array}{c}E_{50}^{r e f} \\
\left(\mathrm{kN} / \mathrm{m}^{2}\right)\end{array} \\
4490,85\end{array}$} & \multirow{2}{*}{$\begin{array}{c}\begin{array}{c}E_{\text {oed }}^{r e f} \\
\left(\mathrm{kN} / \mathrm{m}^{2}\right)\end{array} \\
3143,60\end{array}$} & \multirow{2}{*}{$\begin{array}{l}v_{u r} \\
0,2\end{array}$} & \multirow{2}{*}{$\begin{array}{l}\mathrm{m} \\
0,8\end{array}$} & \multirow{2}{*}{$\begin{array}{c}\begin{array}{c}\mathrm{c}^{\prime} \\
(\mathrm{KPa})\end{array} \\
5\end{array}$} & \multirow{2}{*}{$\begin{array}{l}K_{0}^{n c} \\
0,577\end{array}$} & \multirow{2}{*}{$\begin{array}{l}\phi^{\prime} \\
\left({ }^{\circ}\right) \\
25\end{array}$} & \multirow{2}{*}{$\begin{array}{c}\text { OCR } \\
1,53\end{array}$} \\
\hline 1,2 & - & 10 & & & & & & & & & & & \\
\hline 10 & - & 20 & 0,04 & 1,6 & 26945,10 & 8981,70 & 6287,19 & 0,2 & 0,8 & 15 & 0,546 & 27 & 3,12 \\
\hline 20 & - & 30 & 0,025 & 1,1 & 34821,36 & 11607,12 & 8124,98 & 0,2 & 0,8 & 15 & 0,546 & 27 & 2,27 \\
\hline 30 & - & 40 & 0,025 & 1,1 & 34821,36 & 11607,12 & 8124,98 & 0,2 & 0,8 & 15 & 0,546 & 27 & 1,78 \\
\hline 40 & - & 50 & 0,025 & 1 & 33163,20 & 11054,40 & 7738,08 & 0,2 & 0,8 & 20 & 0,546 & 27 & 1,47 \\
\hline 50 & - & 60 & 0,025 & 1 & 33163,20 & 11054,40 & 7738,08 & 0,2 & 0,8 & 20 & 0,546 & 27 & 1,84 \\
\hline 60 & - & 70 & 0,04 & 1 & 20727 & 6909 & 4836,30 & 0,2 & 0,8 & 20 & 0,546 & 27 & 1,57 \\
\hline 70 & - & 80 & 0,04 & 1 & 20727 & 6909 & 4836,30 & 0,2 & 0,8 & 20 & 0,546 & 27 & 1,38 \\
\hline 80 & - & 90 & 0,04 & 1 & 20727 & 6909 & 4836,30 & 0,2 & 0,8 & 20 & 0,546 & 27 & 1,22 \\
\hline 90 & -11 r $x-1$ & 100 & 0,04 & 1 & 20727 & 6909 & 4836,30 & 0,2 & 0,8 & 20 & 0,546 & 27 & 1,10 \\
\hline 100 & -11 r $x-1$ & 110 & 0,04 & 1 & 20727 & 6909 & 4836,30 & 0,2 & 0,8 & 20 & 0,546 & 27 & 1,00 \\
\hline 110 & -11 r -1 & 120 & 0,04 & 1 & 20727 & 6909 & 4836,30 & 0,2 & 0,8 & 20 & 0,546 & 27 & 1,00 \\
\hline
\end{tabular}

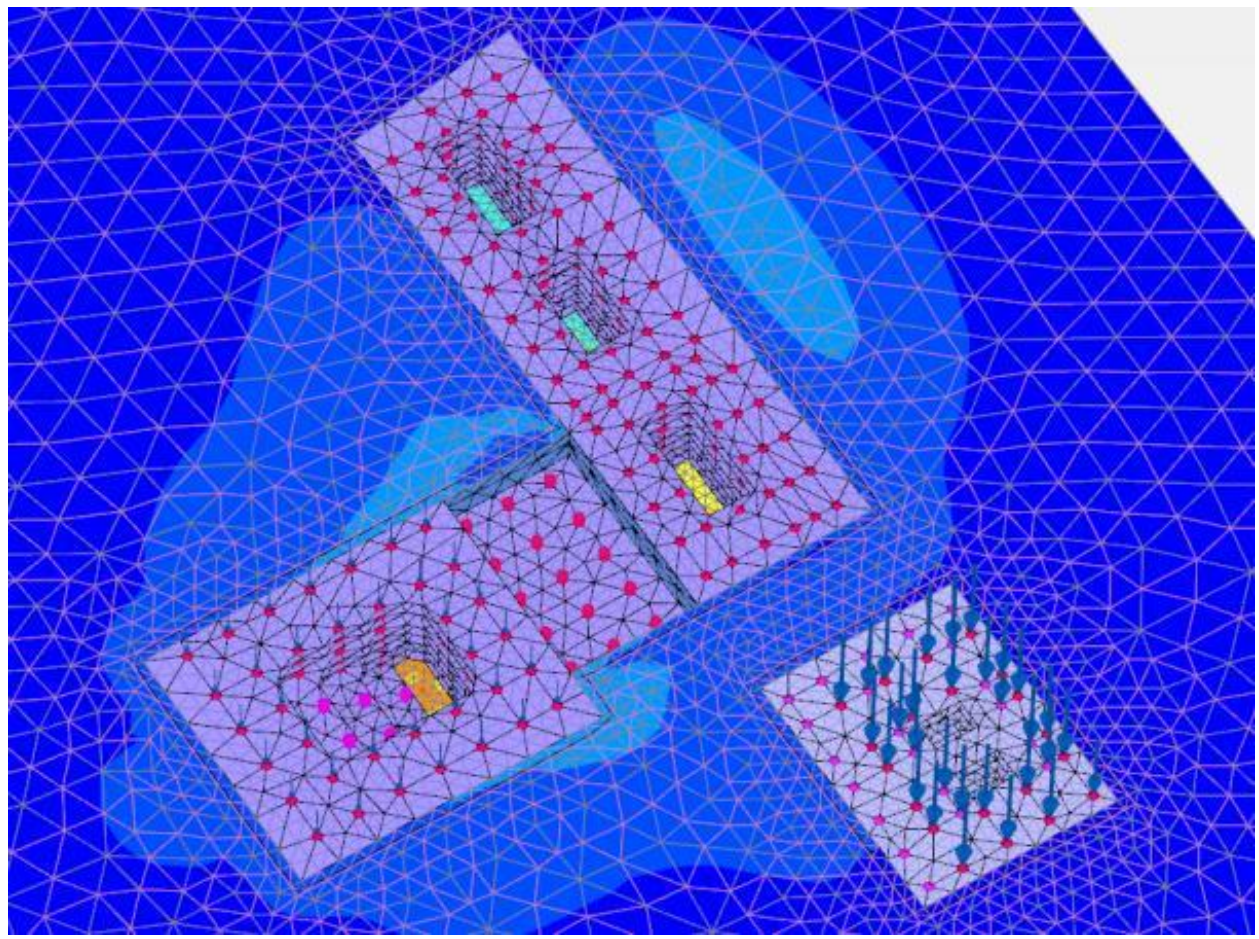

Gambar 4. Hasil pemodelan struktur pada program

Untuk memverifikasi hasil pemodelan pada program finite element ini dilakukan perhitungan tegangan lateral efektif sebagai perbandingan (Gambar 5). 


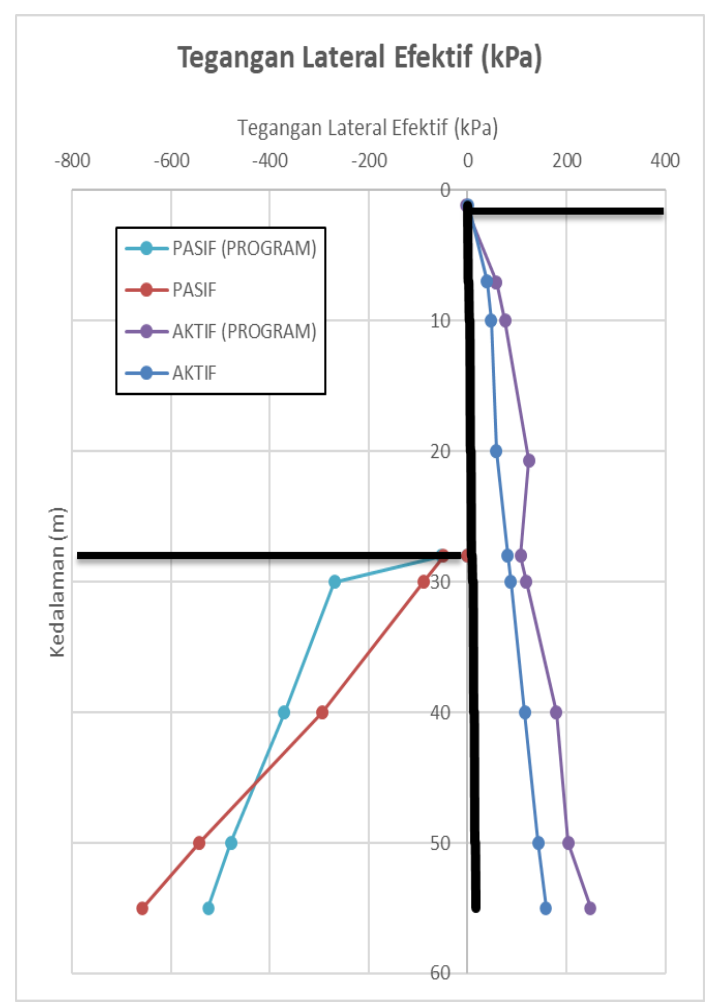

Gambar 5. Perbandingan nilai tegangan lateral efektif pada program dan perhitungan

\section{Analisis dinding diafragma bangunan eksisting (Bangunan A dan C)}

Untuk bangunan $\mathrm{C}$, dinding diafragma yang dianalisis hanya pada sisi utara, barat, dan selatan pada tengah bentangan. Berdasarkan analisis yang telah dilakukan, defleksi lateral maksimum terletak pada sisi barat dengan bentuk defleksi lateral pada kondisi eksisting dan setelah dilakukannya pekerjaan galian bangunan B dan connecting basement dapat dilihat seperti pada Gambar 6. Berdasarkan hasil tersebut dapat dilihat bahwa pada kondisi eksisting, defleksi lateral maksimum sebesar 9,563 cm dan seiring dengan dilakukannya pekerjaan galian basement dari bangunan disebelahnya menyebabkan pertambahan defleksi pada dinding sehingga menjadi $10,483 \mathrm{~cm}$.

Untuk bangunan A, dinding diafragma yang dianalisis yaitu pada setiap sisi (utara, barat, timur, dan selatan) tengah bentangan dengan defleksi lateral maksimum terbesar terletak pada sisi barat bangunan A dengan defleksi sebesar $5,120 \mathrm{~cm}$. Setelah pekerjaan galian bangunan B dan connecting basement dilakukan, defleksi bertambah menjadi $5,252 \mathrm{~cm}$ namun pada sisi ini setelah dinding diafragma dibuka tidak memberikan pertambahan defleksi pada dinding. Bentuk defleksi lateral sisi utara dinding pada kondisi eksisting dan setelah dilakukannya pekerjaan galian bangunan B dan connecting basement dapat dilihat seperti pada Gambar 7. Berdasarkan hasil tersebut dapat dilihat bahwa pada kondisi eksisting, defleksi lateral maksimum sebesar 4,794 cm. Seiring dengan dilakukannya pekerjaan galian basement bangunan B dan connecting basement, defleksi terlihat mengarah ke sisi utara sehingga defleksi menjadi $4,525 \mathrm{~cm}$. Setelah dinding dibuka, defleksi kemudian bertambah lagi menjadi 4,532 $\mathrm{cm}$. (Catatan: tanda minus hanya menunjukkan arah) 


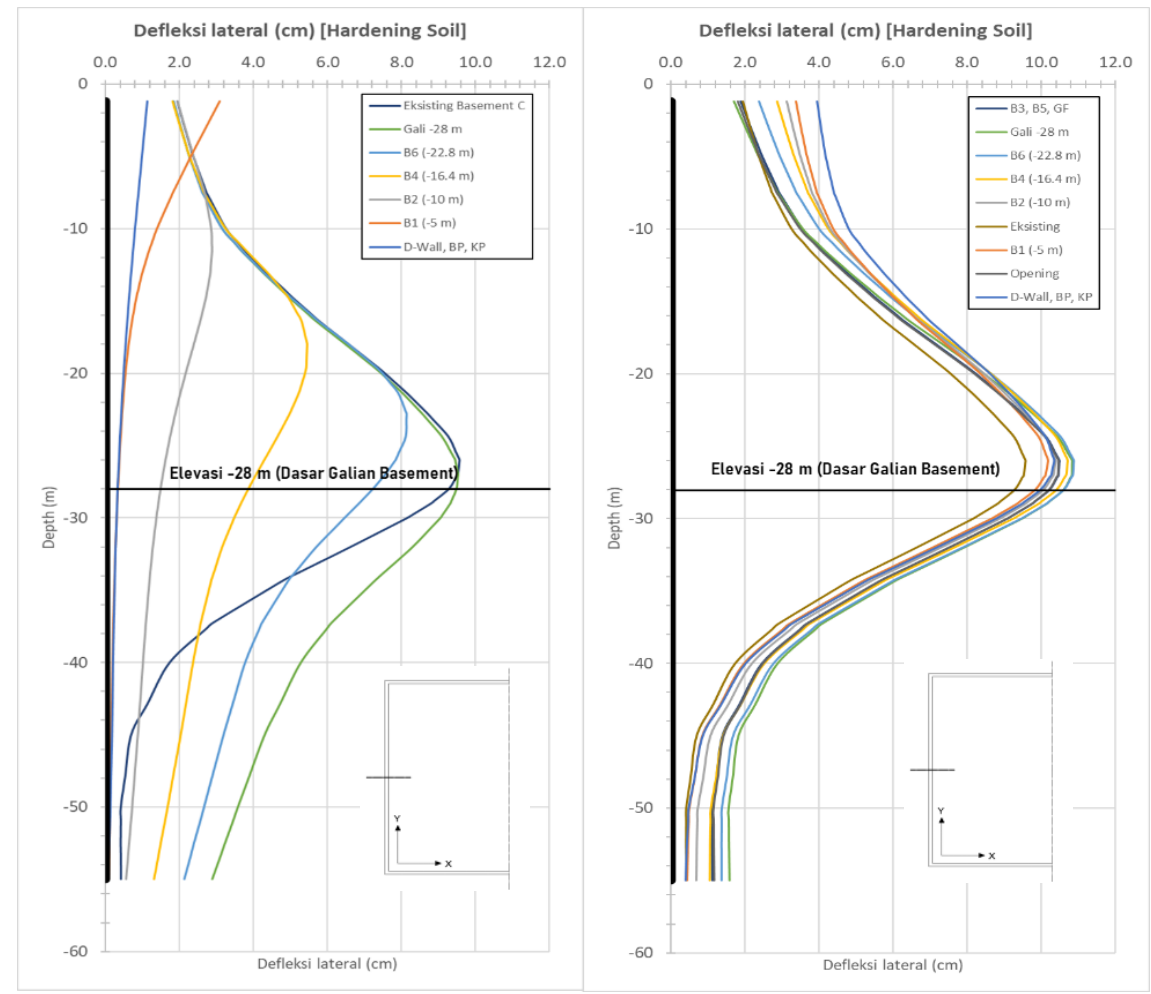

Gambar 6. Defleksi lateral dinding diafragma bangunan C sisi barat pada kondisi eksisting (kiri) dan kondisi setelah galian bangunan B dan connecting basement dilakukan (kanan)

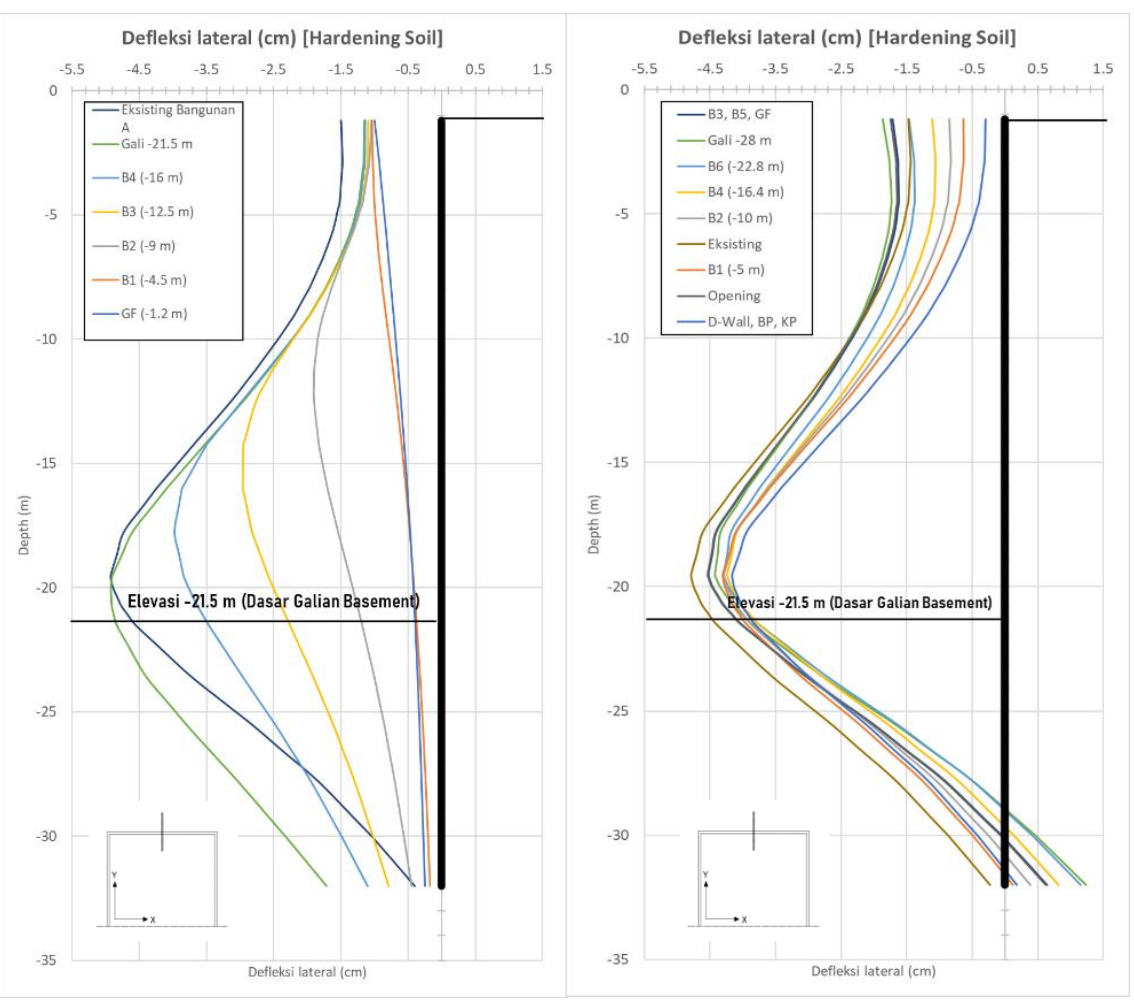

Gambar 7. Defleksi lateral dinding diafragma bangunan A sisi utara pada kondisi eksisting (kiri) dan kondisi setelah galian bangunan B dan connecting basement dilakukan (kanan) 


\section{Analisis pelat lantai basement bangunan $\mathrm{C}$}

Untuk melihat pengaruh dari bukaan dinding, yang dianalisis hanya pelat lantai dari basement bangunan C. Berdasarkan analisis yang telah dilakukan, pertambahan gaya aksial pada pelat lantai sisi utara dan timur bangunan lebih besar dibandingkan sisi selatan dan barat bangunan. Hal ini dapat diakibatkan oleh pelat lantai basement yang ikut menerima beban dari dinding akibat tekanan lateral tanah yang mendorong dinding setelah dinding dibuka. Lokasi dari gaya aksial maksimum tersebut berada pada sisi utara yang dekat dengan bukaan dinding (corner). Pertambahan gaya aksial tersebut dapat dilihat pada Gambar 8 untuk sisi utara.

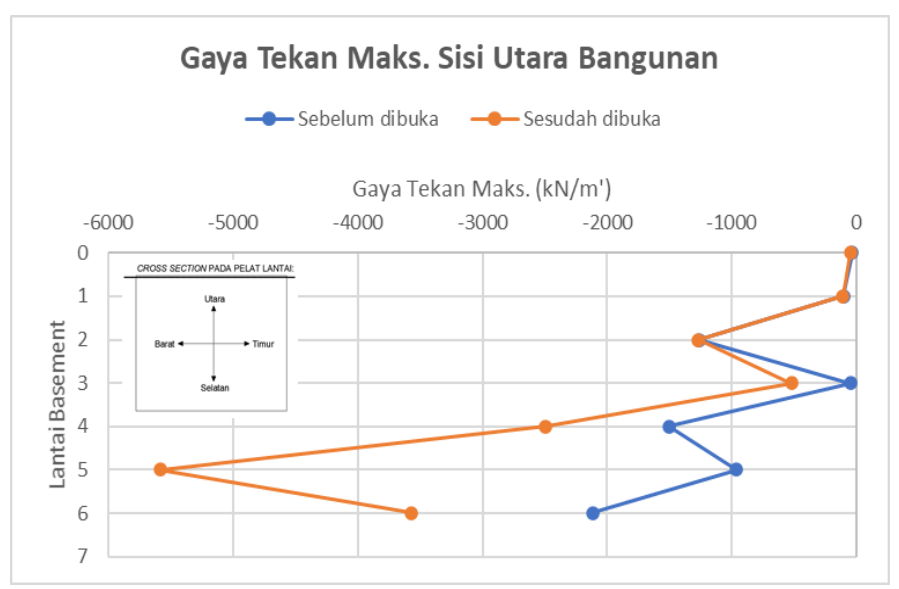

Gambar 8. Grafik perbandingan gaya tekan maksimum pada pelat lantai bangunan C (sisi utara)

\section{Analisis stabilitas global dan lokal}

Sesuai dengan SNI 8460-2017 Pasal 11.1, analisis dari galian dalam harus meninjau kemungkinan terjadinya failure yang bersifat lokal dan global. Untuk Bangunan B, perlu ditinjau kondisi dari dasar penggalian seperti apa, mengingat bahwa bahaya yang dapat ditimbulkan akibat kegagalan di bagian dasar penggalian sangat berbahaya untuk basement tersebut. Berdasarkan analisis yang telah dilakukan dengan metode Terzaghi (1943) untuk kasus $\mathrm{D}>\mathrm{B} \sqrt{2}$ dasar galian aman terhadap heave dengan faktor keamanan sebesar 2,89>1,25. Analisis stabilitas global dilakukan dengan menggunakan program sebagai kalkulasi safety dinyatakan aman dengan melebihi syarat minimum dari SNI dengan faktor keamanan 2,912 > 1,5 pada tahapan penggalian $-28 \mathrm{~m}$.

\section{KESIMPULAN DAN SARAN}

\section{Kesimpulan}

a. Secara keseluruhan, defleksi dari dinding diafragma bangunan A, B, C, maupun connecting basement dengan model material Hardening Soil masih dalam batas yang aman sesuai SNI 8460-2017 yaitu dengan batasan nilai maksimum sebesar $14 \mathrm{~cm}$.

b. Opening pada dinding diafragma tidak mempengaruhi deformasi pada keseluruhan struktur secara signifikan apabila dibandingkan dengan deformasi pada tahapan konstruksi sebelumnya (kondisi dimana seluruh pekerjaan basement bangunan B dan connecting basement telah selesai). Hal ini dapat dilihat pada grafik yang menunjukkan perbedaan deformasi yang sangat kecil, terutama pada dinding yang berada disebelahnya (dinding diafragma bangunan $\mathrm{C}$ )

c. Berdasarkan perhitungan manual, dasar galian aman terhadap basal heave dengan Faktor Keamanan sebesar 2,89 dimana telah melebihi syarat batas SNI 8460:2017 sebesar 1,25 dan 
telah melebihi syarat angka minimum dari stabilitas global dengan faktor keamanan 2,912 > 1,5

\section{Saran}

a. Pada penelitian ini penulis hanya menggunakan model material lanjutan yaitu Hardening Soil. Penulis menyarankan untuk menggunakan model material lanjutan yang lebih kompleks untuk mendapatkan hasil yang lebih akurat.

b. Pada analisis yang dilakukan, pemodelan air tanah digunakan dengan tipe kalkulasi tekanan air phreatic (tekanan air hidrostatik). Disarankan untuk memodelkan sistem dewatering dengan pemodelan steady state flow sehingga kondisi air dapat dibuat semirip mungkin dengan kondisi di lapangan saat dilakukannya dewatering dan dapat diamati bagaimana penurunan yang terjadi di sekitar permukaan tanah dekat galian.

c. Disarankan untuk memperhitungkan beban gempa dikarenakan penelitian yang dilakukan memberikan hasil yang tidak terlalu signifikan akibat bukaan pada dinding dengan kondisi statik.

\section{REFERENSI}

Brinkgreeve, R., \& Shen, R. (2011). Structural Elements and Modelling Excavation in Plaxis. Power Point Presentation Files. Delf, Netherlands.

BSN. (2017). SNI 8460:2017: Persyaratan Perancangan Geoteknik.

Calvello, M., \& Finno, R. (2004). Selecting Parameters to Optimize in Model Calibration by Inverse Analysis. Computer and Geotechnics, 31, 410-424.

Dinakar, K., \& Prasad, S. (2013). Effect of Deep Excavation on Adjacent Buildings by Diaphragm Wall Technique Using PLAXIS. Journal of Mechanical and Civil Engineering (IOSRJMCE), 26-32.

Gaba, A. R., Simpson, B., Powrie, W., \& Beadman, D. R. (2002). Embedded retaining walls: guidance for economic design.

Kung, G. T., Hsiao, E. C., Schuster, M., \& Juang, C. H. (2007). A neural network approach to estimating deflection of diaphragm walls caused by excavation in clays. Computers and Geotechnics Science Direct, 34, 385-396. doi:https://doi.org/10.1016/j.compgeo.2007.05.007

Lim, A., Ou, C. Y., \& Hsieh, P. G. (2010, April). Evaluation of Clay Constituive Models for Analysis of Deep Excavation Under Undrained Conditions. Journal of GeoEngineering, 5(1), 9-20.

Ou, C. Y. (2006). Deep Excavation Theory and Practice. Taylor \& Francis Group.

Ou, C. Y. (2016, April). Finite Element Analysis of Deep Excavation Problems. Journal of GeoEngineering, 11(1), 1-12.

Terzaghi, K. (1943). Theoritical Soil Mechanics. New York: John Wiley \& Sons Inc. 